No. 14(18)

\title{
OGONKI, czyli \\ ILONA KOPOCIŃSKA \\ (1938-2016)
}

\section{Antoni Smoluk}

DOI: $10.15611 / \mathrm{dm} .2017 .14 .07$

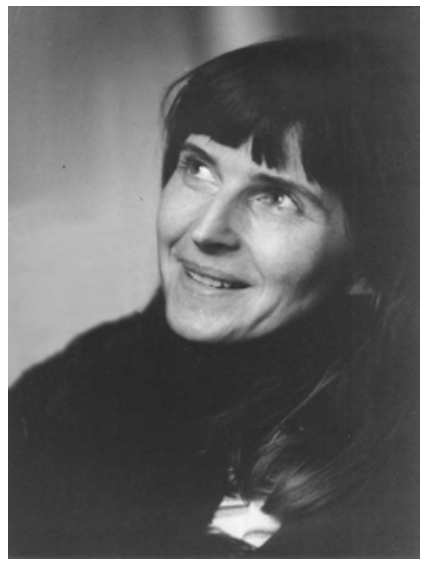

Non dominus domo, set domus domino honestanda est.

Profesor Wydziału Matematyki Uniwersytetu Wrocławskiego Ilona Kopocińska urodziła się 11 stycznia 1938 roku w Ostrzeszowie. Jej ojciec był prawnikiem, mieli własny dom w rynku. Aniela Grell - to jej panieńskie imię i nazwisko; węgierska Ilona pojawiła się później. Komunistyczne władze w szeregu represji, jakie spadły na miasto, zlikwidowały liceum salezjańskie w Ostrzeszowie. Ilona w tej szkole pobierała nauki. Rodzina wysyła ją do Krakowa; trafiła do liceum TPD na Kazimierzu. W szkole tej uczyły się głównie sieroty żydowskie. Liceum to zakończyła maturą. Gorzki smak władzy ludowej, przeniesiony do Polski na bagnetach krasnoarmiejców, poznała więc wcześnie. Jej ojcu zabroniono uprawiać zawód prawnika, brat spędził kilka lat w więzieniu, a ona w obcym mieście kończyła szkołę średnią. Mieszkała na stancji. Jej gospodyni, prosta krakowska mieszczka, w dniu pogrzebu Tadeusza Banachiewicza powiedziała swej pensjonarce: Dzień dzisiejszy jest historyczny. Żegnamy największego polskiego uczonego. Dożyliśmy czasów, w których uczonych już nie ma - wszyscy wymarli. Pozostała rzesza, jakże liczna, akwizytorów działających w nauce wypunktowanych i habilitowanych na cymbałach, trąbie i alefie 15-tym.

\footnotetext{
Antoni Smoluk

Wrocław University of Economics

email: math@ue.wroc.pl

ORCID: 0000-0002-9990-037X
} 
Zaraz po maturze rozpoczęła studia matematyczne na Uniwersytecie Jagiellońskim. Po dwóch latach edukacji w Krakowie przeniosła się do Wrocławia na zastosowania matematyki. W 1960 roku uzyskała dyplom magistra i rozpoczęła pracę w Katedrze Matematyki Wyższej Szkoły Ekonomicznej we Wrocławiu; kierownikiem tej katedry był w owym czasie docent Stefan Zubrzycki. Pracę nad rozprawą doktorską zakończyła w 1966 roku u profesora Józefa Łukaszewicza, późniejszego rektora Uniwersytetu. Po obronie doktoratu na Wydziale Matematyki, Fizyki i Chemii przeszła na Uniwersytet. Zajmowała się systemami kolejkowymi, niezawodnością i biomatematyką. Teoria badań operacyjnych powstała w czasie drugiej wojny światowej. Badania operacyjne to głównie logistyka - organizacja wielkich przedsięwzięć. Ta nowa dziedzina nauki obejmuje także problematykę bombardowań dywanowych, funkcjonowanie lotniskowców jako systemów kolejkowych, bada nawet proporcję między liczbą kranów z ciepłą i zimną wodą. Od tej proporcji zależy czas zużyty przez jednostkę wojskową na toaletę i posiłek. Teoria kolejek dla niespecjalisty brzmi dziwnie, a nawet śmiesznie, jednak jest to rzecz śmiertelnie poważna. Maszyny bojowe wracające po wykonaniu zadania lecą na resztkach paliwa i bywają uszkodzone. Kolejność lądowania i czas obsługi to czynniki decydujące o życiu pilota. Systemy kolejkowe to specjalne układy cybernetyczne charakteryzujące się intensywnością sygnałów wejściowych, liczbą kanałów obsługi i czasem obsługi. Tematyka ta była przedmiotem badań skromnej i cichej Ilony. Piękne dwa modele kolejkowe, związane są ze zwykłą kroplą wody. Gutta cavat lapidem non vi, sed saepe cadendo. To pierwszy model jednostajnej kolejki z samoobsługą. Drugim modelem kolejkowym są krople wody wiszące na gałęzi lub drucie. W tym modelu obsługujący wybiera stojącego w kolejce. Tak powinno być w kolejkach dla lekarzy i tak jest na lotniskowcach - ląduje pierwszy ten samolot, którego czas się kończy.

Po doktoracie z teorii kolejek i przejściu na uniwersytet w 1967 roku habilitowała się z tej dziedziny w 1972 roku. Tytuł profesora matematyki nadano jej późno, bo w 1988 roku. Odznaczenia państwowe i liczne nagrody Polskiego Towarzystwa Matematycznego oraz Ministerstwa Nauki wieńczą jej pracę naukową, dydaktyczną i organizacyjną. Na dworze barona Hugona Dionizego Steinhausa - księciem matematyków jest oczywiście tylko Carl Friedrich Gauss - była paziem; w warsztacie Józefa Łukaszewicza była już czeladnikiem. Jej majstersztykiem jest dzieło w języku angielskim, które ukazało się w znanej serii Dissertationes Mathematicae, poświęcone teorii od- 
nowy: kiedy i w jakiej kolejności wymieniać części, by czas naprawy był najkrótszy; praca ta syntetyzuje programowanie sieciowe z systemami kolejkowymi. Rozprawę tę, traktującą głównie o problemie konserwatora, recenzowali znani matematycy: Zbigniew Ciesielski, Czesław Nardzewski i Kazimierz Urbanik.

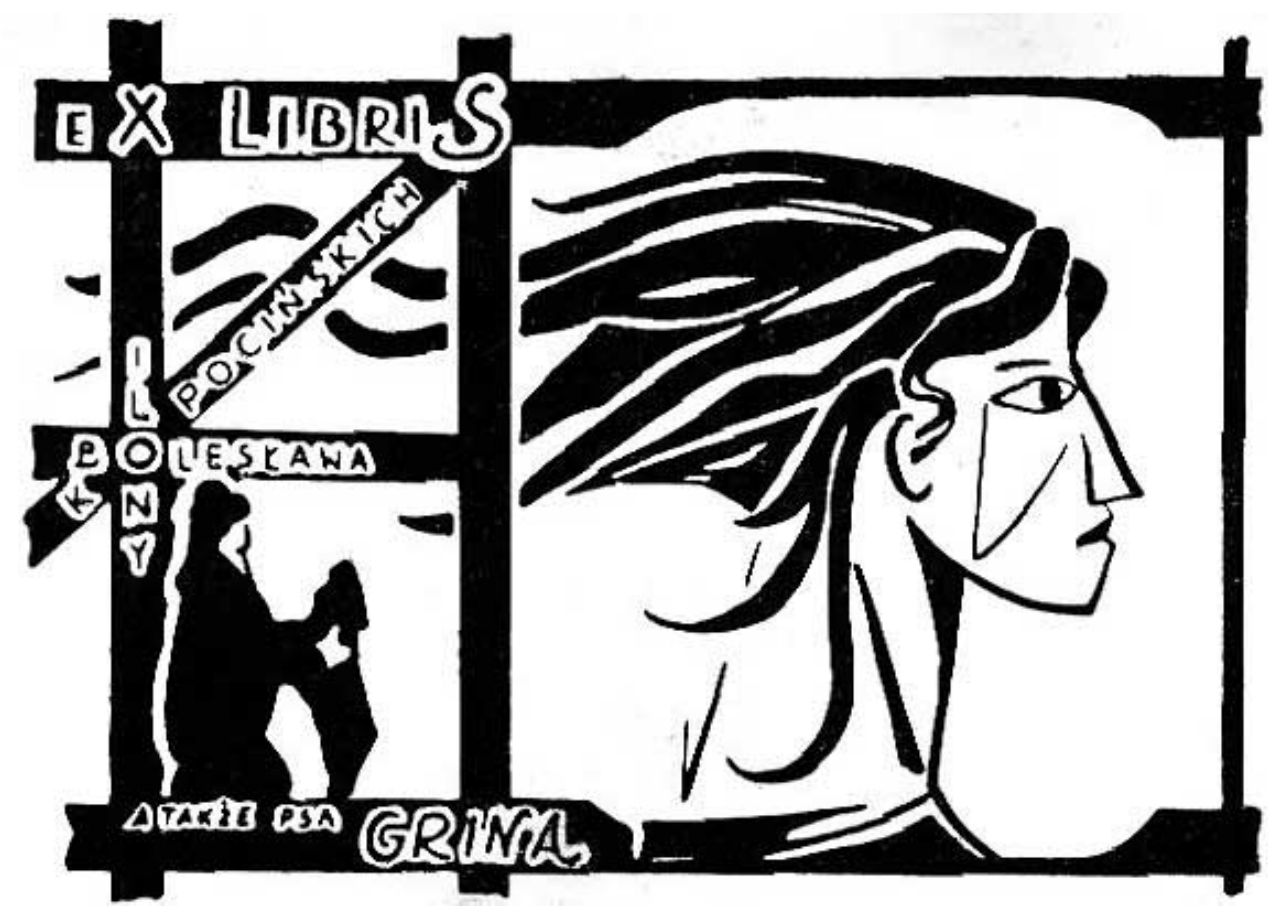

Exlibris. Grafika B. Kopocińskiego

Około roku 1966 w Warszawie odbyła się wielka konferencja statystyków, może kolejny kongres Międzynarodowego Instytutu Statystycznego; organizatorem tego spotkania był GUS, a patronował mu premier Polski. Z celebrytów obecnych pamiętam tylko Hugona Steinhausa. Ilona miała referat sekcyjny. W czasie dyskusji zabrała głos profesor Ira Koźniewska z Warszawy. Między paniami wywiązała się krótka wymiana zdań zakończona kompromisem: obie pozostały przy swoich poglądach. W salach Urzędu Rady Ministrów przy Krakowskim Przedmieściu, tam gdzie rączego rumaka ujeżdża Piękny Książę, premier wydał przyjęcie dla uczestników kongresu. W drzwiach budynku stał prezes GUS-u z małżonką i witał wszystkich 
uczestników, a było ich około ośmiuset, uściskiem dłoni i słowami: Bonsoir, Monsieur! Istny Wersal. Kelnerzy zaczęli roznosić kieliszki z czystą wyborową, a wiktuały były na stolikach pod ścianami. Silna grupa mężczyzn, głównie Rosjan, zajęła punkty strategiczne przy drzwiach, skąd wychodzili kelnerzy: tace po trzech krokach były już puste. Podobnie szybko znikały przekąski ze stolików. Ilony i Steinhausa nie widziałem. Piękny spektakl dał statystyczne high life. Po piętnastu minutach wyszedłem z rautu na kolację do baru mlecznego.

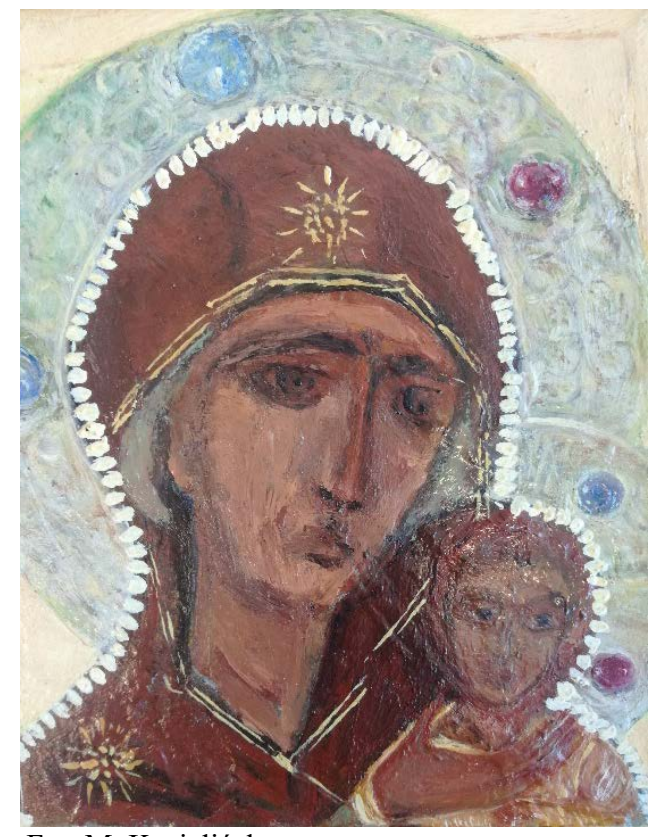

Fot: M. Kosielińska

Ikona Ilony

Całe życie poświeciła kolejkom i dydaktyce; uczyła matematyki przyrodników: biologów, geologów i geografów. Była osobą niezwykle skromną i łagodną, cichą, służącą swoją wiedzą wszystkim zainteresowanym. Zawsze pomagała: pożyczała i dawała na cele dobre i słuszne, jak kościół i klasztor w Zbarażu, obiady dla biednych dzieci et cetera. Kochała ludzi, szczególnie dzieci; na jej pogrzebie obecni byli sąsiedzi z pociechami jeszcze w wózkach. Żałobną uroczystość ograniczono do rodziny i przyjaciół.

W stanie wojennym jako dyrektor Instytutu Matematyki ds. dydaktyki rozumem i uporem chroniła pracowników prześladowanych i poszukiwanych przez władzę. To dzięki niej nie zwolniono profesora Bolesława Gleichgewichta. 
Dla odprężenia malowała. Szczególnie piękne są jej kopie ikon. Naturalnie ikon nie malowała, lecz je pisała. Jej kopie mogą konkurować z dziełami zawodowych twórców tego gatunku. Zamieszczoną reprodukcję podarowała Helenie, tej ze wspólnej wycieczki do Kretowic. Kardynał Gulbinowicz również otrzymał od niej w darze ikonę. W grudniu 1981 roku, po ogłoszeniu stanu wojennego, wzorując się na obrazie Bolka, namalowała obraz Wrona. Nazwa obrazu nawiązuje do skrótu WRON - Wojskowa Rada Ocalenia Narodowego. Atmosfera obrazu Ilony jest przejmująca. Widać w nim słynną nowelę Żeromskiego Rozdziobia nas kruki, wrony, a także odniesienie do obrazu Gersona Powrót Kazimierza Odnowiciela. Literacki tryptyk Żeromskiego jest niewątpliwie pod wpływem kilkunastu kartonów Grottgera z cyklu Wojna. Obraz Ilony jest jej osobistym protestem przeciw decyzji wojskowych o stanie wojennym w Polsce. Uprawiała również tkaninę artystyczną. Lubiła szeroko rozumianą sztukę: malarstwo, rzeźbę, architekturę. W praskiej galerii obrazów stała zachwycona przed licznymi tam dziełami impresjonistów. Była zapaloną turystką. Samotnie spacerowała po wzgórzach Masywu Centralnego we Francji; z napotkanymi pasterzami ucinała rozmowy w ich ojczystym języku. W Polsce przypuszczalnie nie ma znanej miejscowości, w której nie byłoby śladów stóp Ilony i Bolka.

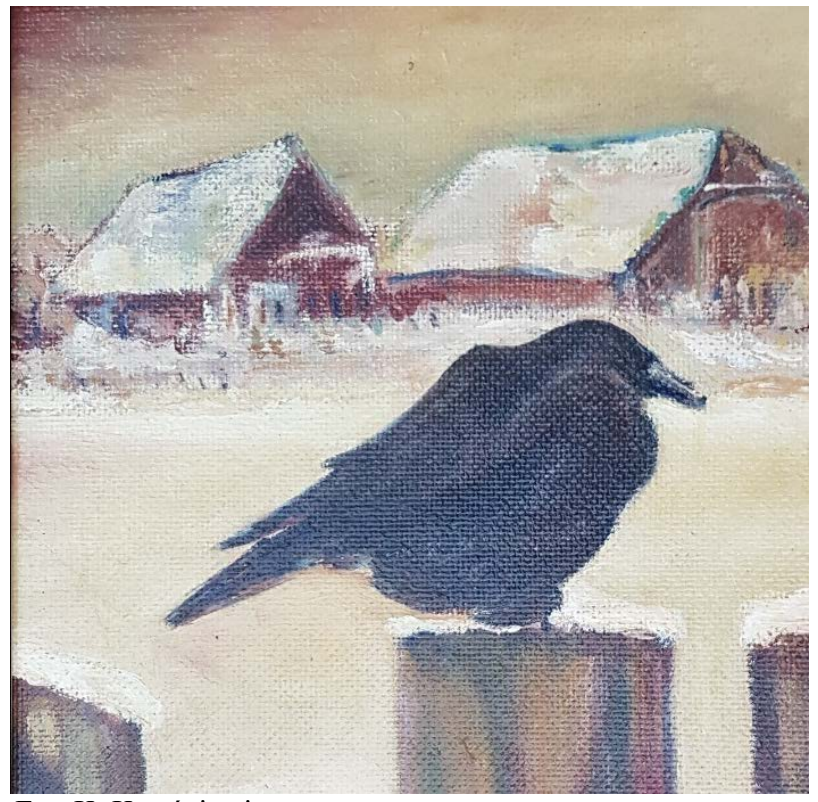

Fot: K. Kwaśniewicz

Wrona - stan wojenny, malowała Ilona 
Adam Chełmoński, profesor prawa administracyjnego i gospodarczego na Uniwersytecie Wrocławskim, bratanek słynnego malarza Józefa Chełmońskiego, miał w zwyczaju wyróżniać ludzi, których lubił, landrynką. Wyciągał z kieszeni nagi cukierek i wręczał go osobie cenionej przez siebie ze słowami: Masz, pan. Zapaproszona landrynka Chełmońskiego nobilitowała, była swego rodzaju wieńcem laurowym. Profesor Ilona Kopocińska miała podobny obyczaj. Wycieczki ożywiała pralinkami - zwykle malagą: uczestnikom wędrówki wręczała po czekoladce; wzmacniała ciało i radowała duszę.

Kochała Kresy. Wyjazd najętym samochodem z Tarnopola do Kretowiec i Zbaraża był dramatyczny; odpadło koło od pędzącego starego moskwicza. Stał się jednak cud - z wypadku wyszliśmy tylko lekko potłuczeni. Po odszukaniu rozrzuconych w przydrożnym zbożu części udało się jakoś to koło przyczepić i samochód był zdatny do dalszej niepewnej jazdy. Kretowce wieś od wieków całkowicie polska, bez jednego Rusina. Tu w czasie wojny znaleźli schronienie uciekinierzy z Wołynia, tu kryli się Polacy przed zagonami bisurmańskimi. W Kretowcach była prawdopodobnie komenda AK na województwo tarnopolskie. Hipotezę tę uwiarygodnia aresztowanie w 1949 roku księdza Kazimierza Klee - proboszcza z Kretowiec. Brakujący dzwon, jeden z trzech, z przykościelnej dzwonnicy nie opuścił wygnańców z Kretowiec; po 24 dniach tułaczki trafił do Lipinek Łużyckich 31 grudnia 1945 roku. Gniazdo bociana widoczne na załączonym zdjęciu przywołuje obsesyjnie nostalgiczne słowa: Hej ptaki do Polski, a my w świat daleki. Wybitny wrocławski matematyk Kazimierz Urbanik urodził się w Krzemieńcu - wołyńskich Atenach. Ilona ze swych licznych podróży po kresach przywiozła kamień z góry Bony, który wręczyła Urbanikowi. Krzemieniecka skała przeniosła go w zawsze mile wspominane lata dzieciństwa. Wspaniałe nawiązanie do chyba najlepszego wiersza Zbigniewa Herberta Kamyk.

\author{
Kamyk jest stworzeniem \\ doskonatym \\ równy samemu sobie \\ pilnujacy swych granic
}

Krzemieniec dziś jest zapomnianym ukraińskim miasteczkiem, gdzie restauracja daje polskim turystom ziemniaki ze zjełczałą słoniną. W czasach królewskich powiat krzemieniecki obejmował również rejon Zbaraża i Kretowiec. 


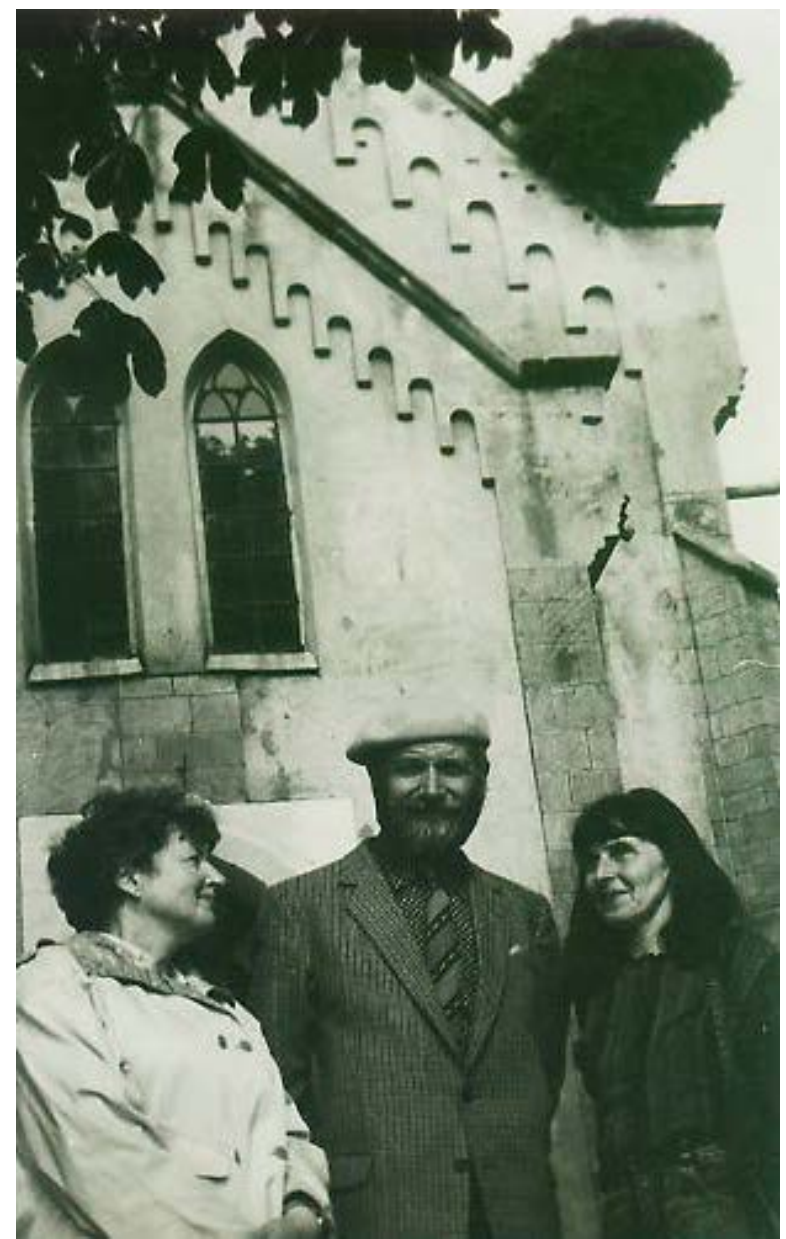

Fot. B. Kopociński

Kretowce, 12 czerwca $1991 \mathrm{r}$.

Od prawej: Ilona, A.S., Helena Lindyberg

W swoim domu letniskowym miała pracownię malarską zbudowaną według zaleceń sztuki i architektury. Pracownia malarska Ilony i jej męża Bolka - profesora Bolesława Kopocińskiego - jest obszernym studio z dużym panoramicznym oknem wychodzącym na północ. Bolek jest twórcą nowego kierunku w malarstwie, zwanego ironią Kopocińskiego. Jest to fantastyczny, surrealistyczny pejzaż miejski: w Amsterdamie umieszcza Katedrę Lwowską, Trafalgar Square zaś, zamiast Nelsona, zdobi duma Rosji-Car Kałakoł. W pokoju Katedry Zastosowań Matematyki, gdzie pracowali Ilona i Bolek, wisi jego obraz będący pastiszem dzieła Brouwera przedstawiającego bójkę 
w karczmie. Postacie z obrazu Flamanda mają twarze obecnych i byłych pracowników katedry. Słowo „ironia” w tym szkicu ma takie same konotacje jak $\mathrm{w}$ pojęciu ironii romantycznej: jest to rodzaj sprzeczności pomiędzy bytem idealnym i jego realnym odpowiednikiem. Można więc także mówić o ironii naukowej. Barokowe nazwy argumentów $x$ i wartości $y$ w modelu ekonometrycznym $y=f(x)$, jako zmiennych objaśniających i objaśnianych, kojarzy się ze specjalnymi nożyczkami do objaśniania świec.

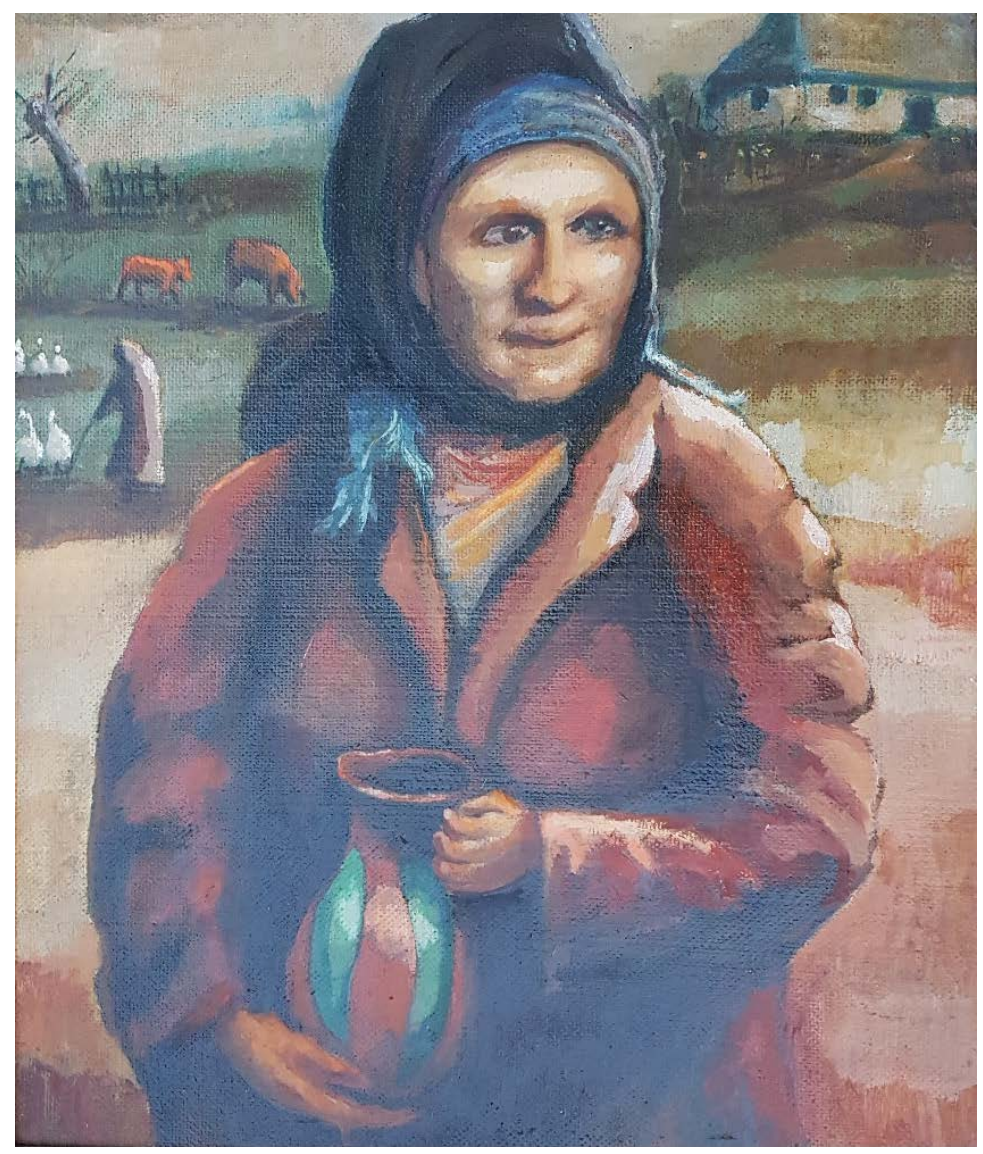

Mleczarka. Malował B. Kopociński

Obraz „Mleczarka” jest rezultatem rozmów o jakości nabiału gospodyń wiejskich. Bolek uważa, że na tę jakość ma wpływ koszula gospodyni. Mleko, jego zdaniem, cedzono przez koszulę; grzybnia w niej żyjąca zakwaszała swoistymi smakami mleko. Obraz jest naśladownictwem „Mleczarki” 
Jana Vermeera. Ma on przedstawiać moją mamę. Teorie Kopocińskiego potwierdza zachowanie się mamy, która naturalnie cedziła mleko przez odpowiednią płachtę, konopną chyba, którą prała po każdym użyciu. Mleko przechowywane w piwnicy, w niepolewanych garnkach zwanych ładuszczykami, miało smak zależny od naczynia. W ściankach niektórych garnków żyły dobre bakterie i one wydawały smaczne kwaśne mleko i śmietanę; były też garnki o złej grzybni, z których mleko miało gorzkawy smak. Te garnki mama od czasu do czasu wyparzała wrzątkiem, by zniszczyć zły posiew bakteryjny.

Do oryginalnych teorii Bolka należy również problem dentystyczny. Każdy chce mieć długo zdrowe i piękne zęby. Zęby za życia szybko się psują, lecz po śmierci ta część ciała zachowuje się w dobrym stanie najdłużej. Miłośnikom ładnych zębów te swoje spostrzeżenia dawał pod rozwagę. Jego malarstwo ewoluuje - od mistycznego realizmu poprzez symbolizm i ironię do prymitywizmu. Niedługo będziemy mieli w Polsce trzech znanych prymitywów: żebraka Nikifora z Krynicy, górnika Teofila Ociepka ze Śląska i matematyka Prokopa z Wrocławia.

Kopocińscy wiele lat cieszyli się pięknym czarnym spanielem; był to Grin, kudłaty jak sam rokita, łagodny zaś jak anioł. W pewnym okresie życia pies ten był ich nieodłącznym towarzyszem. Portretowali go jak najlepszego przyjaciela; spoczął w końcu pod kamienną płytą, z wyrytym napisem Grin, w ogrodzie domu letniskowego.

W języku domowym Ilona była Koniuszą, a Bolek Miśkiem. Misiek jest prosty i słoneczny, a Koniusza złożona i mglista jak większość pojęć Bolka: prokop, kupa, Trifon zarezan i właśnie Koniusza.

Pierwsza wyprawa krzyżowa odbyła się pod hasłem Dieu le veut - Bóg tak chce. Zawołanie to miało usprawiedliwić zbrojne działania. Szarmanccy Francuzi rozszerzyli te słowa do powiedzenia: Ce que veut la femme, Dieu le veut - życzenie kobiety jest życzeniem Boga. Bolek często, w różnych sprawach, pouczał Ilonę. Jego, czasami nawet cierpkie, uwagi znosiła ze stoickim spokojem. Znaczący uśmiech mówił wszystko. W ich domu działo się zawsze tak, jak zaplanowała to Ilona. Bolek i Ilona to dwie połówki jednej pomarańczy. W każdej kolejce dawali pierwszeństwo innym. Na konferencjach i zjazdach naukowych pozostawali zwykle bez miejsca przy stole i kiełbasek przy ognisku. Czesław Nardzewski lubił, gdy przyjaciele, koledzy i studenci nazywali go Sławkiem. Bolesław nie jest gorszy od Czesława, więc chciałem, aby i on był Sławkiem. Zaprotestował, bo ustąpił swoje miejsce w świątyni Sławy innym. Teoria kolejek z ustępującymi pierwszeństwo klientami czeka 
na opracowanie. Gdy w kolejce pojawi się dwóch ustępujących, system zostanie prawdopodobnie zablokowany. Wszędzie byli razem; ich koledzy żartowali znanym przysłowiem: nieszczęścia chodza parami. Ilona miała rzadki dar śmiania się z własnej osoby; anegdotę o parze nieszczęść sama kilkakrotnie przypominała. Dbała o Bolka jak matka, siostra, żona i przyjaciółka. Robiła to, co robił Bolek. Znany malarz wrocławski - Stanisław Kukla, ich sąsiad, miał pod Wrocławiem dom letni, zwany Kuklówką. Odwiedzali go tam od czasu do czasu. Kukla raz próbował poczęstować ich wybornym topionym serem. Ilona spojrzała na Bolka, Bolek podziękował, odmówił, wtedy ona na wszystkie sposoby zaczęła przekonywać malarza, że oni czegoś takiego nigdy w życiu nie jedli i nie mogą jeść, chociaż wiedzą, że to rzecz smaczna. Byli niezależni aż do śmieszności. Zdarzyło się, że na wspólnej wycieczce ten sam skład osobowy, który był w Kretowcach, poczęstowałem kanapkami. W każdej były dwa gatunki najlepszej wędliny, a było to w czasach, gdy wędlina nie była mięsną strukturą napompowaną wodą z kazeiną - szynka była szynką, a polędwica polędwicą. Chleb był ze świeżym masłem, a w środku listek kruchej sałaty. Całość zawinięta w śniadaniowy papier. Przerwa śniadaniowa wypadła w okolicy Srebrnej Góry. Akurat trafił się wiejski Burek, zwabiony zapachem. Moje kanapki profesorowie bez rozwijania rzucili psu. Helena, naśladując króla Szwecji, który po zapaleniu papierosa przez Szymborską na obiedzie noblowskim, sam zapalił, również rzuciła swoją kanapkę psu. Zawsze uważała się za Szwedkę. Ja, prostak - дурново крісті він кричу nycmi - swoją kanapkę zjadłem; nie poszedłem za wzorem elity akademickiej. Zdarza się, że wychodzisz z sercem na dłoni, a nikt go nie chce - chyba że dla psa. W kanapkach, którymi częstowałem, było również moje serce.

Była piękną kobietą o wspaniałych bujnych włosach, zielonych oczach i orlim nosie. Figurę miała drobną, wzrostu była niskiego. Nosiła odzież projektowaną i szytą przez Bolka - haute couture w najlepszym wydaniu. Suknie te kochała i w taką suknię ubrano ją po raz ostatni. Kochała ludzi, zwierzęta i rośliny. Ptaki rozpoznawała po śpiewie; rzadko trafiały się drzewa, krzewy i rośliny zielne, których nazw nie znała.

Była chyba człowiekiem szczęśliwym. Si apud bibliothecam hortulum habes, nihil deerit. Miała dom z podręczną biblioteką przy dużym ogrodzie $\mathrm{z}$ bogatą kolekcją floksów. Zgodnie z myślą Cycerona niczego jej nie brakowało do pełni życia.

Żyła po spartańsku. Złoto to tylko ładny, żółty metal odporny na działanie atmosfery. Jej wypowiedzi są wzorcami lakonicznego stylu. Daleka była od teorii prawdy mówionej: im więcej słów, im głośniej, tym większa nauka. 
Strumień słów zawsze rozpalał gwiazdki ironii w jej oczach: cichy wróg logo rhei. Dbała o innych, zapominając o sobie. Kochaj bliźniego, sobą pogardzaj.

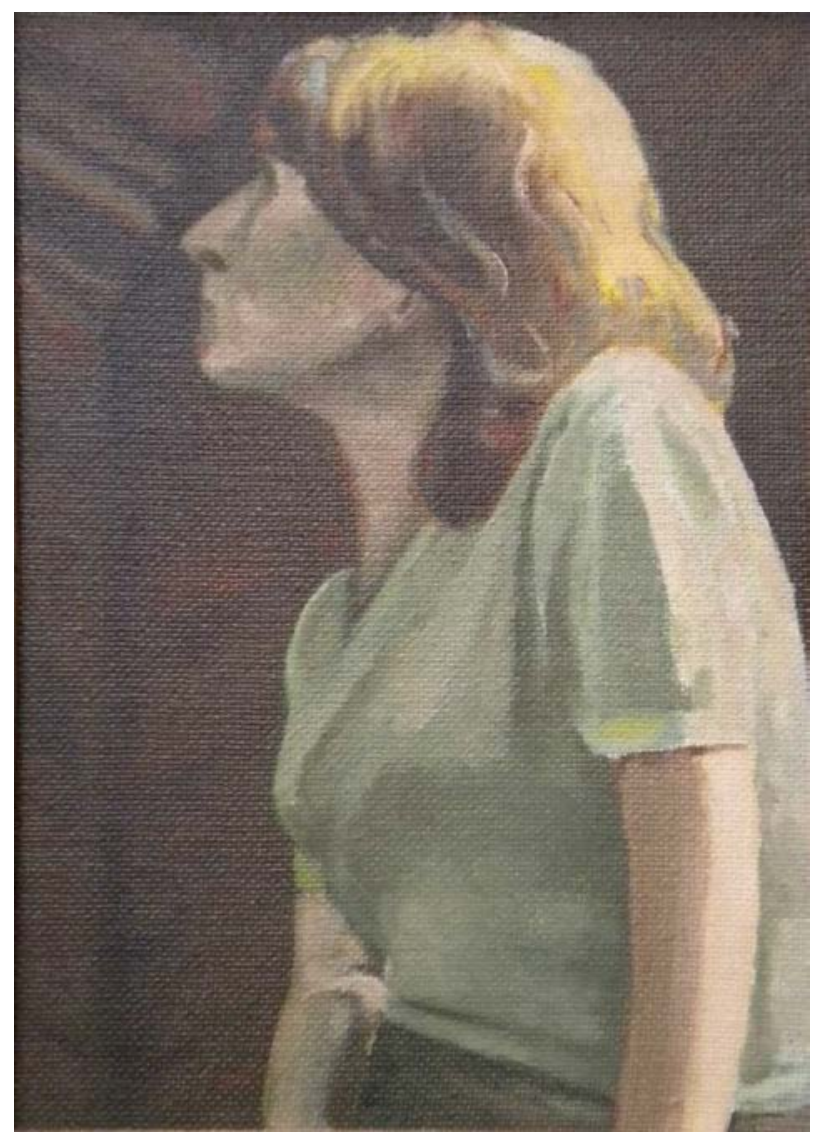

Portret Ilony. Malował B. Kopociński

Pierwszego października 1961 roku rozpocząłem pracę w Katedrze Matematyki Wyższej Szkoły Ekonomicznej we Wrocławiu. Ilona, pracująca już w tej katedrze, poleciła moją osobę Stefanowi Zubrzyckiemu. Rektor Józef Fiema, na wniosek Zubrzyckiego, dał mi angaż. Na życie do pierwszej wypłaty otrzymałem od Ilony 500 zł. W owym czasie większość katedr miała małe podręczne biblioteki. W naszej były zbiory zadań, standardowe podręczniki i słowniki. Znalazłem w niej ciekawą pozycję popularyzującą matematykę. Ładna ta książka - tłumaczenie z języka rosyjskiego - oprócz prostych zadań zawierała również problemy trudniejsze, nierozwiązane. Takim 
nierozwiązanym w owym czasie problemem była hipoteza o czterech barwach. Zwróciłem uwagę Ilony na kolorowanie map: piękne i ważne zadanie mamy, należy tylko usiąść i je rozwiązać. Ilona z całą powagą na twarzy, ale iskierkami uśmiechu w oczach, potwierdziła moje spostrzeżenie. Nad problemem czterech barw, z dużymi przerwami, pracowałem pięćdziesiąt pięć lat. Dowód zakończono w lutym 2016 roku. Dwa woły robocze dowodu - to produkt map oraz pojęcie minimalnego lokalnego kolorowania. Produkt redukuje kolorowanie mapy do barwienia dwóch map mniejszych, a lokalne minimalne kolorowanie $\mathrm{w}$ wierzchołku rozszerza się na zgodne kolorowanie całej mapy. Zgodne minimalne kolorowanie w wierzchołku to barwienie państw, mających wspólny wierzchołek, tylko dwoma kolorami, lub trzema, ale pod warunkiem że jeden kolor jest użyty tylko raz; pojęcie to pozwala harmonizować kolory przy sklejaniu map. Dowód tego twierdzenia dedykuję Ilonie.

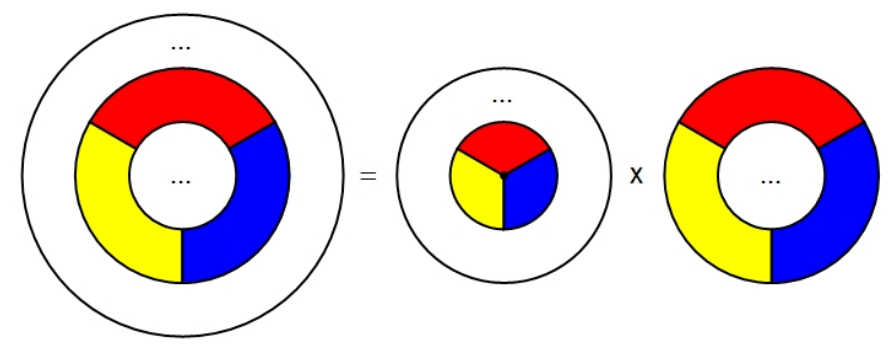

Rys. 1. Iloczyn map

Źródło: opracowanie własne.

Miała specyficzne poczucie humoru, nigdy nie zaprzeczała, lecz subtelnym uśmiechem dawała do zrozumienia, że sprawy mają się inaczej. Zdarzyło się, że kelner restauracji w Świeradowie nie wpuścił do lokalu Kopocińskich z psem; w rewanżu Ilona napomknęła o drzewie genealogicznym pana kelnera i wysoko notowanym Pedigree Grina.

Ilona przeszła na Uniwersytet. Zmieniła miejsce pracy bez porozumienia stron: rektora WSE Józefa Popkiewicza z rektorem Uniwersytetu Alfredem Jahnem. Rektor Popkiewicz nie wyraził zgody, więc musiała pisać wypowiedzenie w jednym miejscu i podanie o przyjęcie w innym. Popkiewicz był niezadowolony, bo tracił dobrego pracownika i jeszcze do tego miał dodatkowe zajęcie. Nie uległ natarczywym prośbom Ilony. Mówił więc, że Kopocińska powinna się nazywać Kłopocińską. Rektor Jahn witał Ilonę lampką koniaku. Był wybitnym uczonym, odważnym i dzielnym mężczyzną. Przeciwstawił 
się pierwszemu sekretarzowi partii w województwie, ciężko ranny przemógł zbira, a na dodatek był człowiekiem szlachetnym, z klasą. De mortuis nil nisi bene. Była personifikacją dobra: czuła, litościwa, hojna. Starała się nikogo nie urazić, być miła i uprzejma dla wszystkich. Jeśli nawet widziała błąd w cudzym rozumowaniu, kwitowała sprawę wszechobejmującym słowem możliwe. Zdarzyło się, że Ilona w towarzystwie Bolka i trzeciej osoby zwiedzała muzeum. Bolek pędził do przodu jak wyżeł, a ten trzeci kontemplował i zwlekał; Ilona była rozdwojona, bo nie wiedziała, jak zjednoczyć te krańcowości.

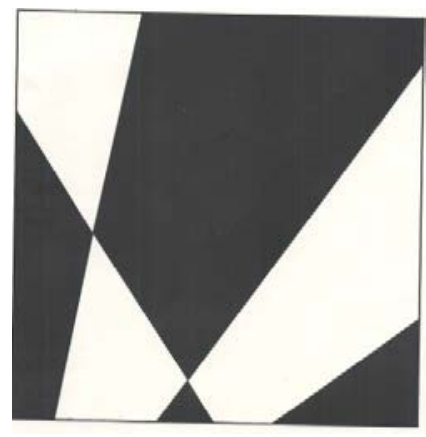

Możliwe

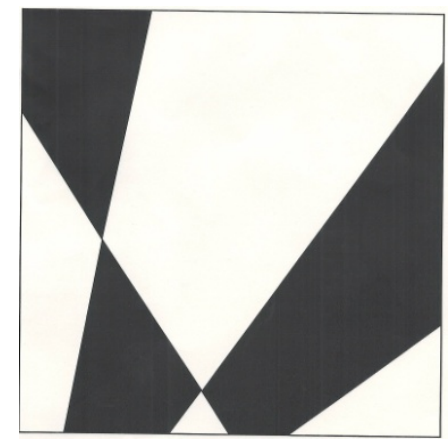

Także możliwe

Źródło: opracowanie własne.

Byliśmy na wspólnych wczasach zimowych w Głuchołazach. Wieczory poświęcone rozmowie o matematyce i sztuce niekiedy były zakrapiane alkoholem. W owych latach było to dobro rzadkie, cenione najwyżej. Ilona jednakowoż swoje porcje wylewała ukradkiem do doniczki; udawała, że pije i dotrzymuje towarzystwa. Niszczyła tym sposobem kwiat i marnowała cenny trunek. Jasność umysłu i świeże spojrzenie na podchmielonych oponentów decydowały o wstrzemięźliwości Ilony. Ilona potrafiła jednym ciągiem wypić halbę piwa. Podobał jej się czterowiersz o napitkach.

$$
\begin{gathered}
\text { Miody syca, } \\
\text { piwo warza, } \\
\text { wino robia } \\
\text { i gorzatke goniq. }
\end{gathered}
$$

Miody są syte, piwo jest zwarzone, wino - zrobione, a gorzałka wypędzona. Oby na zawsze z naszego kraju. 


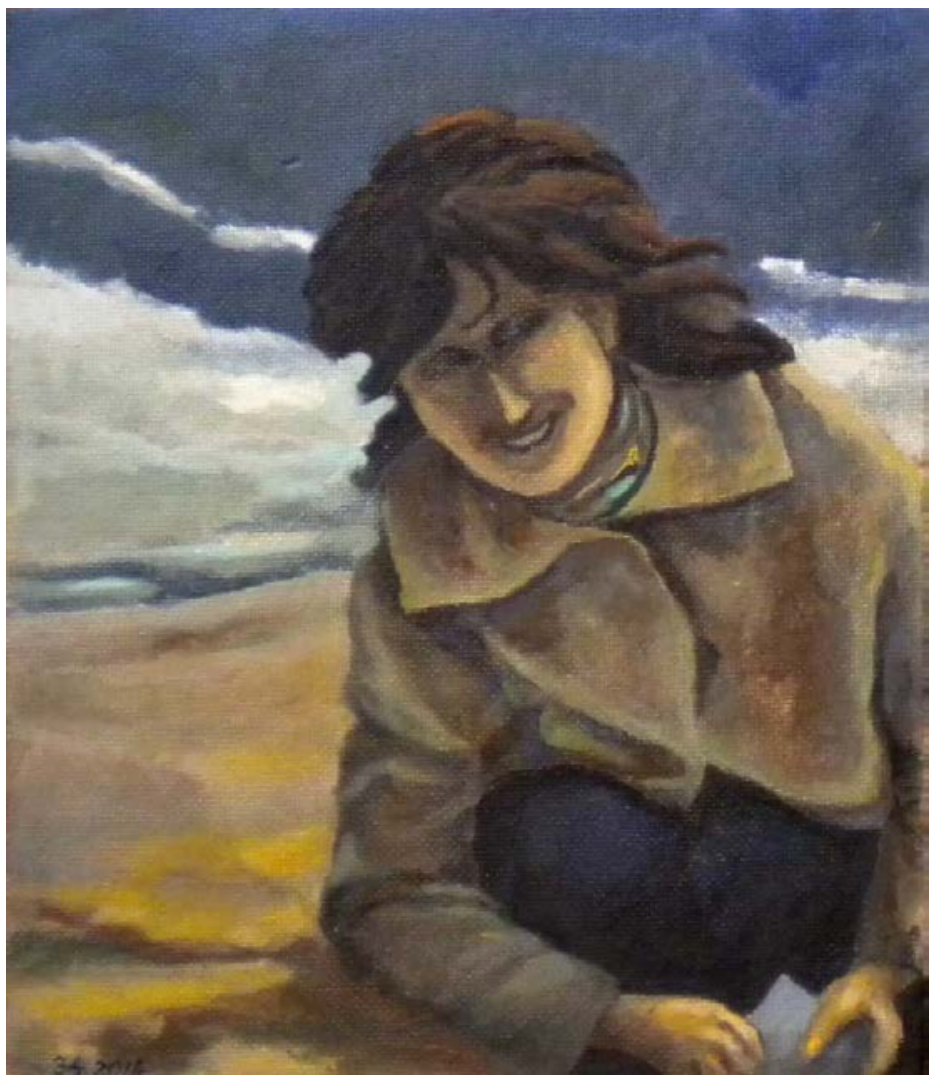

Późniejszy portret Ilony. Malował B. Kopociński

Pomijana w awansie znosiła to z pokorą, bo uważała, że zaszczyty nie mają dla niej znaczenia. Liczyła się praca i służba. Jest nieznanym bohaterem; cierpiała w samotności, dla ludzi była radosna i spokojna. Jej aura udzielała się otoczeniu. Była muzykalna - grała na pianinie.

W nabiał rodzinę Grellów zaopatrywała gospodyni z pobliskiej wsi. Z tą mleczarką związany jest duży obraz przedstawiający króla naszych lasów jelenia. Zdarzyło się, że mleczarka, nieuważnie manewrując swymi konwiami, stłukła wiszące $\mathrm{w}$ przedpokoju duże lustro. W zamian przyniosła obraz rogacza, który zajął pustą ścianę po lustrze. Jeleń, o szlachetnym wyglądzie, ma głowę uwieńczoną gałęzistą koroną, a z tyłu jaśniejsze placki - rodzaj tarczy. Nie jest to kiczowata rzecz - jeleń na rykowisku, lecz przypuszczalnie nawiązanie do myśli 42 psalmu. Jak jeleń pragnie wód bieżacych, tak dusza moja Ciebie Panie. W obrazie widać charakterystyczne dla szkoły kra- 
kowskiej fiolety. Odnosi się wrażenie, że jest to dzieło Siemiradzkiego, chociaż obraz jest sygnowany nieznanym nazwiskiem. Jeleń miał przestrzelone oko i liczne ubytki; dziś, po renowacji, obraz ten zdobi inny przedpokój, a konserwację jego zrobiła znana specjalistka Grażyna Cyunelis.

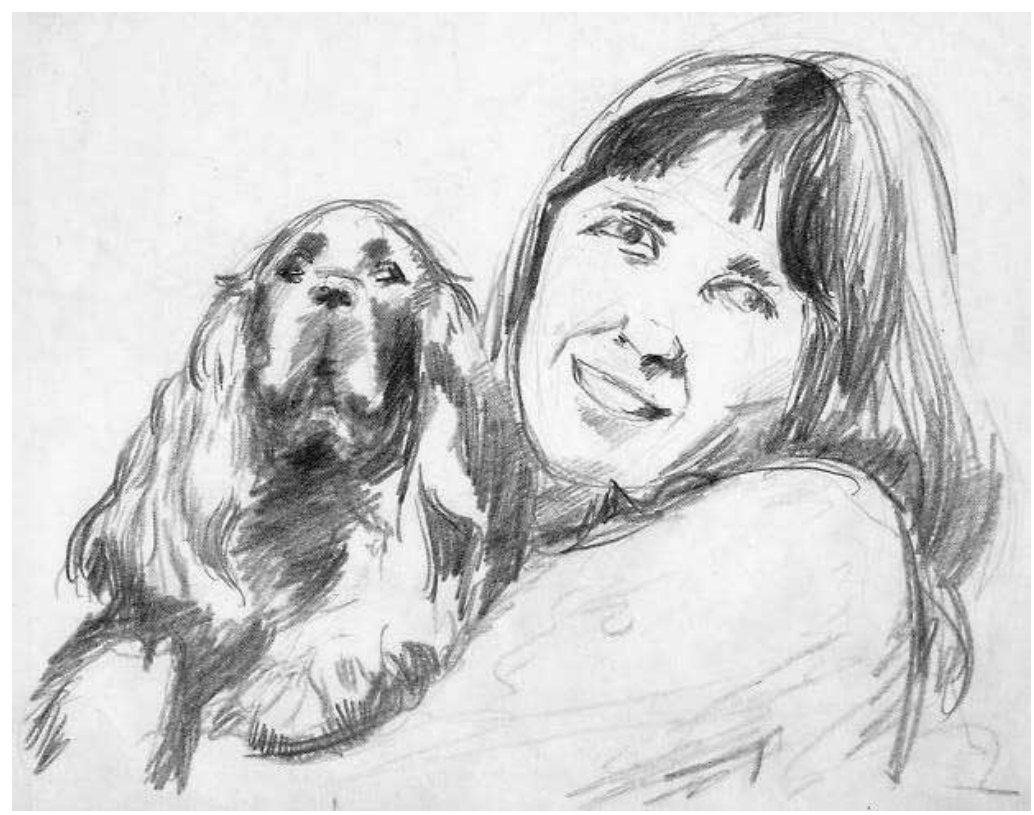

Ilona z Grinem. Grafika B. Kopocińskiego

Ilona Kopocińska zmarła 3 sierpnia 2016 roku w szpitalu w Trzebnicy. Wcześniej w Ostrzeszowie, 5 czerwca 2016 roku, udar mózgu powalił ją i pozbawił świadomości. Była to śmierć psychiczna; ciało jeszcze chciało żyć. Zwłoki jej spoczęły w grobowcu rodzinnym w Ostrzeszowie, niedaleko pomnika Powstańców Wielkopolskich. Poszliśmy, choć nikt nas nie wzywat, bo taki byt nasz święty obowiązek. Te słowa powstańców z ich pomnika odnoszą się też do Ilony. Czyniła dobrze, bo taki był jej święty obowiązek. Nad jej grobem przemawiał profesor Piotr Biler, dziekan Wydziału Matematyki - kolega i przyjaciel. Pomnikiem Ilony jest klasztorna skromność, życie w cieniu i służba. Portal kamienicy z numerem 20, w ścianie południowej wrocławskiego Rynku, zdobi tajemniczy łaciński napis:

\section{CUR ITA LANGUIDO DURATURA.}

CUR ITA 8TRENNUE PERITURA. 
Dlaczego to, co przykre i zbędne, umacnia się i trwa, dlaczego to, co pożyteczne i miłe, słabnie i przemija. Jest to ciągle otwarty problem rodu ludzkiego. Chwile szczęścia - moments - chyżo mijają. Chwilo trwaj! Chwilo trwaj! Chwilo trwaj! Na nic to wołanie. Czas zanika, wieczność nadchodzi nieodwołalnie. Nadzieja jest jeszcze w czasie okrągłym jak Słońce, Księżyc i tarcza zegara. Co było, znów będzie, co będzie, już było. Przyszłość jest przeszłością, a przeszłość przyszłością. Życie ma charakter cykliczny, falowy. Powraca. Według Steinhausa pomiędzy duchem a materią jest matematyka. Owszem, lecz pod warunkiem, że matematyka to fale. Fale są myślą zgodną z prawami natury - nauka daleka od metanauki. Fale to byt, metanauka jest niebytem. Rozpoznawalny profesor emanuje fale. Jego wiedzę i szlachetność odbiera się bez słów.

Wrocławski oddział Polskiego Towarzystwa Matematycznego zorganizował 25 listopada 2016 roku, z inicjatywy profesora Władysława Szczotki, kierownika katedry zastosowań matematyki Uniwersytetu Wrocławskiego, spotkanie na cześć Ilony Kopocińskiej, podzielone na dwie sesje. W pierwszej sesji ogólnej piękny życiorys Ilony przedstawił Piotr Biler, a następnie zabrał głos rektor Uniwersytetu Adam Jezierski. Rektor podzielił profesorów na profesorów nadzwyczajnych i zwyczajnych oraz uniwersyteckich. Wśród profesorów wyróżnił elitę - właściwą klasę uczonych, których nazwał profesorami rozpoznawalnymi. Ilona jest właśnie najlepszym przykładem profesora rozpoznawalnego. Po przerwie kawowej odbyła się sesja naukowa, na której były również dwa wystąpienia. Referat pierwszy - profesora Władysława Szczotki - poświęcony był teorii kolejek, od narodzin tej dziedziny aż do lat ostatnich. Mówił o twórcy teorii kolejek - Erlangu, dalej wspomniał o tym, jak kolejki trafiły do Wrocławia. Przywiózł je ze Stanów Zjednoczonych profesor Józef Łukaszewicz. Na koniec wreszcie omówił wkład Ilony do tej nauki. Jest to nauka tycząca się rzeczywistości fizycznej, a nie metafizyka. Językiem kolejek jest probabilistyka. Teoria kolejek jest matematyką stosowaną par excellence. Innej matematyki niż stosowana nie ma, albowiem nie ma nauki o niczym. Nauka jest zawsze o bycie, a nie o nicości. Przypominała o tym profesor Ilona Kopocińska pouczającym żartem o zdezorientowanej załodze balonu. - Gdzie jesteśmy? - W gondoli balonu. Ta odpowiedź precyzyjna i prawdziwa, jak tautologia $p$ implikuje $p$, nie oświeca pasażerów balonu. Jeżeli pod wypowiedzią naukową nie ma substratu materialnego, wtedy jest to nauka pusta - metafizyka. Matematyka jest szczytem piramidy naukowej, mającej silny fundament w naukach empirycznych. Drugi referat wygło- 
sił doktor habilitowany Krzysztof Topolski. Mówił o przyrodniczych zastosowaniach matematyki i pracach Ilony $z$ tej dziedziny. Były to badania wspólne z przyrodnikami. Tworzono modele matematyczne, które pozwalały symulować zachowanie populacji żywych organizmów. Model matematyczny jest wtedy dobry, gdy rzuca nowe światło na stare zadanie i pozwala przyrodnikom zobaczyć prawidłowości poprzednio nieznane. Ważna tu jest nie matematyka, lecz jej użyteczność w konkretnej nauce. Prosto i ładnie objaśniła Ilona na modelu urnowym defekty w kodzie genetycznym. Im model prostszy, tym głębiej sięga w naturę rzeczywistości. Model myśli i podpowiada, czym się natura rządzi. Jest to tylko gruby szkic portretu Ilony. Barw i ożywczego ducha nada mu fantazja Czytelnika.

W latach 60-tych XX wieku Ginter Trybuś podał żartobliwą definicję idealnego mężczyzny. Jest nim osoba mająca żonę, trójkę dzieci, dom, samochód i kochankę. W czasach towarzysza Wiesława samochód uważany był za burżuazyjny luksus nieprzyzwoity w państwie sprawiedliwości społecznej. Definicję profesora Trybusia uzupełniam całkiem na serio definicją idealnej pani; jest to niewiasta mająca męża, co najmniej troje dzieci, dom, wierna i pracowita. Ilonie do tego ideału brakowało tylko dzieci. Jej ojciec, nie widząc potomstwa, psa Grina nazywał wnukiem. Nauka jest zaborcza i wymaga poświęceń - nawet całkowitej rezygnacji z życia prywatnego.

Na zakończenie wspomnę o książce „Siedmiu matematyków”; jest to planowane dzieło, na wzór książki o ekonometrykach [Smoluk 2016]. Ma to być rzecz o moich nauczycielach, kolegach i przyjaciołach: Bronisławie Knasterze, Janie Zamorskim, Stefanie Zubrzyckim, Ilonie Kopocińskiej, Jerzym Łosiu, Eugeniuszu Szczepankiewiczu i Bolesławie Kopocińskim. Na okładce, na wzór tej o ekonometrykach, zdjęcie Ilony zajmie miejsce centralne. Wokół niej kręci się bowiem mój świat matematyczny. Ilona nigdy nie korzystała z przywilejów należnych płci pięknej, stąd męski tytuł zamierzenia. Czy książka powstanie? Nie wiadomo. Człowiek strzela, Pan Bóg kule nosi.

Post scriptum po około roku. Wspomnienie niniejsze jest kolorowym przedrukiem artykułu [Smoluk 2017], z drobnymi uzupełnieniami i zmianami oraz dodanymi ilustracjami. Profesor Ilona Kopocińska żyła w kolorach i należy się jej druk kolorowy. Ponadto problem czterech barw, związany z nią, bez kolorów traci swą istotę. Ocena publikacji jest wysoka. Powiedziano bowiem, że w słońcu Ilony grzeje się miernota. Polskie piekło jest wszędzie. $O$ tempora, o mores, o docti moriones! 
Post scriptum drugie. Doktor Arkadiusz Maciuk poinformował mnie, że esej powyższy został zablokowany pod pretekstem multiplikacji osiągnięć naukowych. Czym jest osiągnięcie naukowe? Nie jest nim na pewno wspomnienie starca o zmarłej koleżance. Osiągnięciem naukowym jest nowa idea lub empiryczna weryfikacja ważnej praktycznie hipotezy. Jeżeli w artykule nie ma wyników własnych, to nie jest on osiągnięciem naukowym. Rozwój nauki mierzy się nie liczbą opublikowanych artykułów i zapisanych stron, lecz prawami nauki, które ułatwiają życie. Dobry artykuł, zawierający nową ideę, może, a nawet powinien, być publikowany - z ewentualnymi drobnymi uzupełnieniami i zmianami - wielokrotnie. Jest to propagacja idei, jednej idei, w różnych miejscach i o różnym czasie, a nie multiplikacja osiągnięć. Trzysta artykułów bez treści jest tylko makulaturą, nie dorobkiem naukowym. Klasycznym przykładem książki bez wiedzy o świecie jest głośny, w swoim czasie, Traktat o dobrej robocie - w powodzi słów utopiono ideę. Spis dziennych czynności wiejskiej gospodyni domowej ma większą wartość poznawczą niż dzieło prezesa Akademii Nauk - największego polskiego filozofa reisty.

Niezwykły termin autoplagiat stał się popularny w polskim środowisku akademickim. Kto go wysmażył, nie wiadomo, lecz tropy wiodą do Krakowa. Powtórna publikacja własnych idei nie jest autoplagiatem, lecz dyfuzją i popularyzacją osiągnięć. O autoplagiacie można mówić tylko w jednym przypadku - wtedy gdy marnujemy zdolności dane nam przez Boga. Okradamy siebie, jeśli zamiast rozwijać posiadane talenty, marnujemy je na pogoń za sukcesem, pieniędzmi lub szeroko rozumianą konsumpcją. Raz jeszcze podkreślam, że w eseju powyższym chodzi o upamiętnienie zmarłej koleżanki i propagację jej osiągnięć. Ważnym elementem jest tutaj wspomniany już wyżej kolor. Bez koloru nie ma obrazów. Dziękuję jednocześnie Wydawnictwu za blokadę, albowiem działanie to przyczyniło się do wylania tych gorzkich uwag o naszej nauce. Nauka bowiem jest kurą znoszącą złote jajka. Obecne działania „góry”, reformujące naukę, podrzynają gardło tej kurze. Chciałbym, by Wydawnictwo było buforem łagodzącym oddziaływanie urzędników na środowisko akademickie. Dieu le veut.

\section{Literatura}

A. Smoluk (2016). Siedmiu z ekonometrii. Wydawnictwo Uniwersytetu Ekonomicznego we Wrocławiu.

A. Smoluk (2017). Profesor Ilona Kopocińska (1938-2016). Ekonometria. Nr 4(58). S. 105-113. 